\title{
Preterm milk as a source of protein for low birthweight infants
}

\author{
A LUCAS AND G J HUDSON \\ Medical Research Council, Dunn Nutrition Unit, Cambridge
}

SUMMARY A total of 588 samples of 24 hour collections of preterm milk obtained during the first month of lactation from 58 mothers of low birthweight infants have been analysed for total nitrogen content. In addition to the expected decline in milk protein content (total nitrogen $\times 6 \cdot 38$ ) seen with postnatal age, a strong negative correlation between milk protein and milk volume output has been shown. Thus, the greater the volume produced, the smaller the chance that preterm milk contains a sufficiently high protein concentration to meet the calculated requirements of low birthweight infants (given the constraints on the infant's volume intake). Postnatal age and the infant's body weight are identified as additional factors which influence the likelihood that theoretical protein needs will be met. It is speculated that the high protein content seen in preterm milk may not necessarily reflect a unique secretory ability of the mammary gland in mothers delivering preterm but may relate more to the low volume of milk produced by many donors.

There have been several reports ${ }^{1-3}$ of differences in protein content between the milk of mothers who have delivered term infants and those delivering preterm, and this observation has been cited in support of preterm milk as a sole diet for preterm infants. It might be supposed that the higher protein content of preterm milk is an evolutionary adaptation to the greater protein requirements for growth of preterm infants, yet the survival of very low birthweight infants is a modern phenomenon and it seems unlikely that there has been any selection pressure for the production of milk of a composition suited to these infants' special needs.

To investigate further the biology of preterm milk we have explored the relation between its total nitrogen content and the volume produced. This study has enabled us to define factors that influence the likelihood of a mother providing her low birthweight infant with a sufficient protein intake to meet his theoretical requirements.

\section{Patients, materials, and methods}

Preterm milk samples from an unselected series of mothers who had elected to express milk for their own low birthweight neonates were studied (the work comprises part of a larger multicentre study on the feeding of preterm infants). The infants of mothers who participated had been admitted to the special care baby unit in Cambridge: the only criterion for exclusion from the study was a birthweight greater than $1850 \mathrm{~g}$. These infants had a mean birthweight of $1136 \mathrm{~g}$ (range 794 to $1799 \mathrm{~g}$ ) and a mean gestational age of 30 weeks (range 26 to 36 weeks).

A total of 588 samples of preterm milk were obtained from well mixed 24 hour collections of freshly expressed milk from 58 mothers during the first month postpartum. Mothers usually expressed milk three hourly during the day (about six expressions per 24 hours), using a mechanical pump. Milk samples were stored at $-20^{\circ} \mathrm{C}$ and 24 hour volume output was recorded. Preterm milk was usually fed to the infant within 24 hours of taking the sample (the feed volume was made up to between 180 and $200 \mathrm{ml} / \mathrm{kg}$ per day by the addition of another milk if insufficient preterm milk had been produced during each 24 hour period).

Before analysis, milk samples were thawed, warmed to $37^{\circ} \mathrm{C}$, and gently but thoroughly mixed by repeated inversion. Total nitrogen was determined on $\mathbf{0 . 2 5} \mathrm{ml}$ portions by a semimicro Kjeldahl method. Milk protein concentration has been calculated using the formula: protein=total nitrogen $\times 6 \cdot 38$.

During the study period the proportion of 
mothers contributing milk samples decreased owing to either failure of continued milk production or discharge of their infant from the unit; thus, of the 58 mothers who provided samples in week one, only 38 did so beyond week three (see below). For analytical purposes the total volume of milk collected from individual mothers during the periods week one, week two, and weeks three to four has been related to the average protein concentration of the total volume produced during each completed period.

In some reported studies on the protein content of preterm milk, mothers have been selected for 'lactational success' in terms of providing fully their infants' volume requirements. ${ }^{4}$ It was an objective of this study to examine an unselected population of donors (albeit a population that our larger multicentre survey suggests is typical of the lactational performance of preterm milk donors in other units. ${ }^{5}$

Approval for the study was obtained from the local hospital ethical committee.

\section{Results}

Influence of birthweight. There was no significant correlation between birthweight and the average protein concentration of preterm milk (total nitrogen $\times 6.38$ ) or the volume of milk produced at one, two, three, or four weeks postpartum.
Correlation between preterm milk protein conten? and stage of lactation. The change in proteir concentration of preterm milk with time (days. postpartum) for the 588 samples analysed is shown in Fig. 1. Although it was found that the relation between protein content and lactational age can be् described by a linear least squares procedure $(\mathrm{P}<0 \cdot 001)$ when logarithms of both protein and tim are taken, the data are described most simply as a rapid fall during the first four to five days followed? by a more gradual linear decline up to 28 days $\vec{P}$ Superimposed on Fig. 1 are the mean protein $\vec{\sim}$ concentrations for the periods days one to two three to four, and five to seven, and for weeks two three, and four. There was a significant fall in mear protein concentration between weeks one and tw\& and between weeks two and three $(P<0 \cdot 001)$, buịo the fall did not reach significance between week@ three and four. It is apparent, however, that the scatter of results around the mean is large.

Correlation between protein concentration of pre $\overline{\mathscr{D}}$ term milk and milk volume. The relation betweer milk protein concentration (total nitrogen $\times 6 \cdot 38$ B and daily volume output in the 588 samples analyse is shown in Fig. 2. Superimposed on these data is $\vec{a}$ horizontal line at $1.45 \mathrm{~g}$ protein $/ 100 \mathrm{ml}$, where represents the lowest milk protein concentratert that would meet the European Society for Paedia商衣

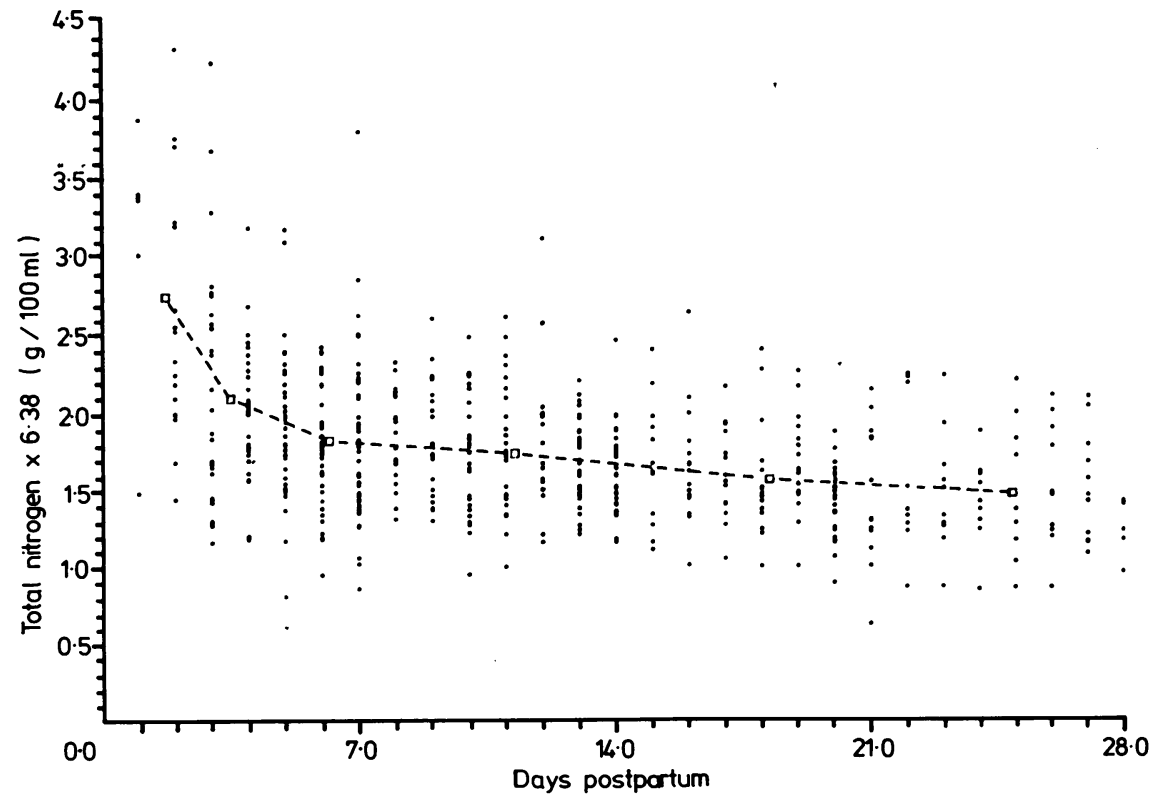

Fig. 1 The protein content (determined as total nitrogen $\times 6 \cdot 38$ ) of all 588 samples analysed are plotted against time (days $\mathbb{D}_{\mathbb{S}}$ postpartum. The mean protein content is shown (squares) for days 1 and 2, days 3 and 4 , days 5 and 7 , and for weeks $2,3,-7$ and 4, and these values are joined by a dashed line. 


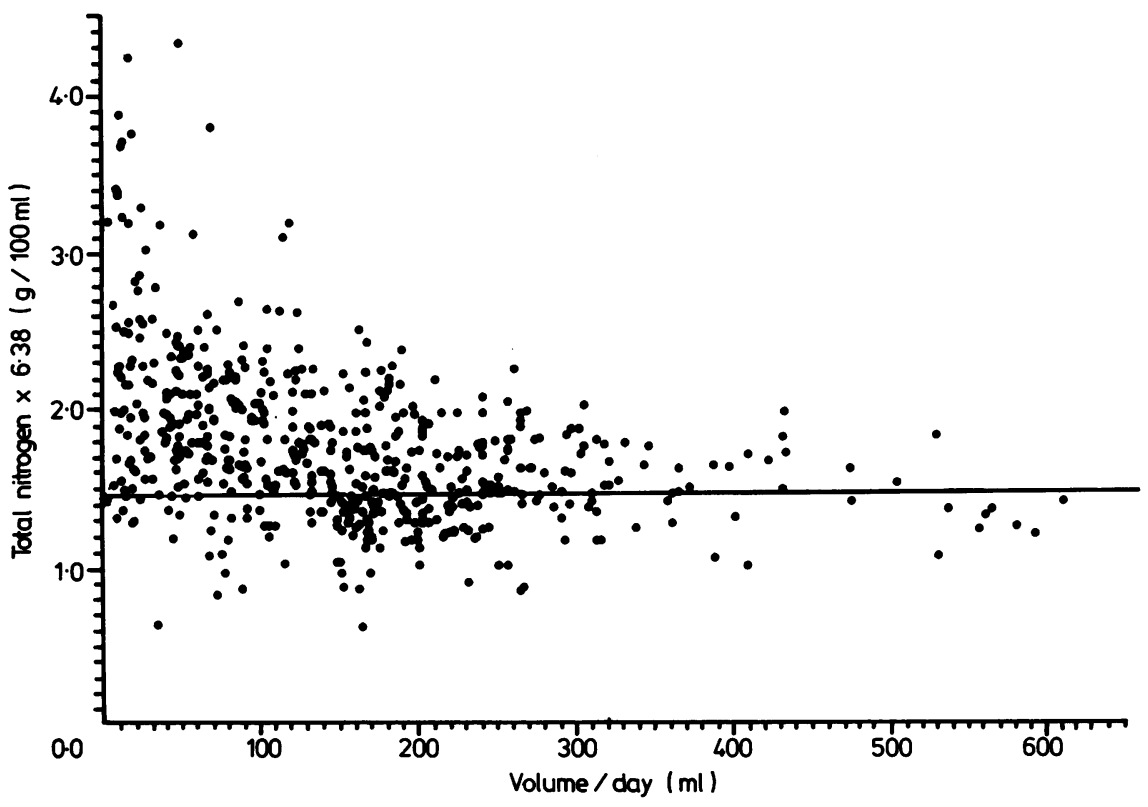

Fig. 2 The same protein values as in Fig. I are plotted against the mother's milk output (ml). A horizontal line is drawn to indicate $1.45 \mathrm{~g}$ protein per $100 \mathrm{ml}$. Below this concentration, a mother supplying her infant with $200 \mathrm{ml}$ of milk/kg/day will not meet the minimum protein intake recommended by ESPGAN. ${ }^{6}$

Gastroenterology and Nutrition (ESPGAN) ${ }^{\mathbf{6}}$ committee recommendations of $2.9 \mathrm{~g}$ protein $/ \mathrm{kg}$ per day for formula fed infants, assuming a maximum intake of $200 \mathrm{ml} / \mathrm{kg}$ per 24 hours (see Discussion). It can be seen that for outputs of less than $100 \mathrm{ml} /$ day, over $90 \%$ of milk samples contain protein concentrations higher than $1.45 \mathrm{~g} / 100 \mathrm{ml}$. With increasing volume of milk production a progressively smaller proportion of samples have a protein content greater than $1.45 \mathrm{~g} / 100 \mathrm{ml}$ : of the 12 samples analysed where volume output was greater than $450 \mathrm{ml} / \mathrm{day}$, only three $(25 \%)$ had a protein concentration that exceeded this value (compared with the proportion of values greater than $1.45 \mathrm{~g} / 100 \mathrm{ml}$ when volume was less than $100 \mathrm{ml} /$ day, by $\chi^{2}, \mathrm{P}<0 \cdot 001$ ). (See below; influence of postnatal age of donor).

Correlation between protein concentration of preterm milk and milk volume in individual mothers. The relation between mean protein concentration and milk volume for individual mothers during the first week postpartum is shown in Fig. 3 (a). There was no significant correlation between protein content and volume produced; however, milk volumes produced at this stage were consistently low. Fig. 3 (b) shows a highly significant negative correlation between milk protein and volume output in week two $(r=-0.57, P<0.001)$ and Fig. 3 (c) shows a weaker but significant relation in weeks three and four combined $(\mathrm{r}=-0.33, \mathrm{P}<0.05)$.

Examination of Fig. 3 shows that if individual donors are selected who produce over $1000 \mathrm{ml}$ of milk per week (sufficient to meet fully the feed volume needs of an infant of around $800 \mathrm{~g}$ or greater), then the proportion of donors in each week of lactation whose milk protein concentrations were greater than $1.45 \mathrm{~g} / 100 \mathrm{ml}$ (that is sufficient to provide $2.9 \mathrm{~g}$ protein $/ \mathrm{kg}$ per day; see Discussion) falls progressively and significantly: see Table.

Table Proportion of mothers in weeks 2, 3, and 4 producing greater than $1000 \mathrm{ml}$ of milk per week, whose mean milk protein concentration exceeds $1.45 \mathrm{~g} / 100 \mathrm{ml}$

\begin{tabular}{lll}
\hline Week & Proportion of mothers ${ }^{*}$ & $\%$ \\
\hline 2 & $18 / 25$ & 72 \\
3 & $14 / 22$ & 64 \\
4 & $1 / 6$ & 17 \\
\hline
\end{tabular}

*The linear trend in proportions (after logit transformation) was significant at the $5 \%$ level. 

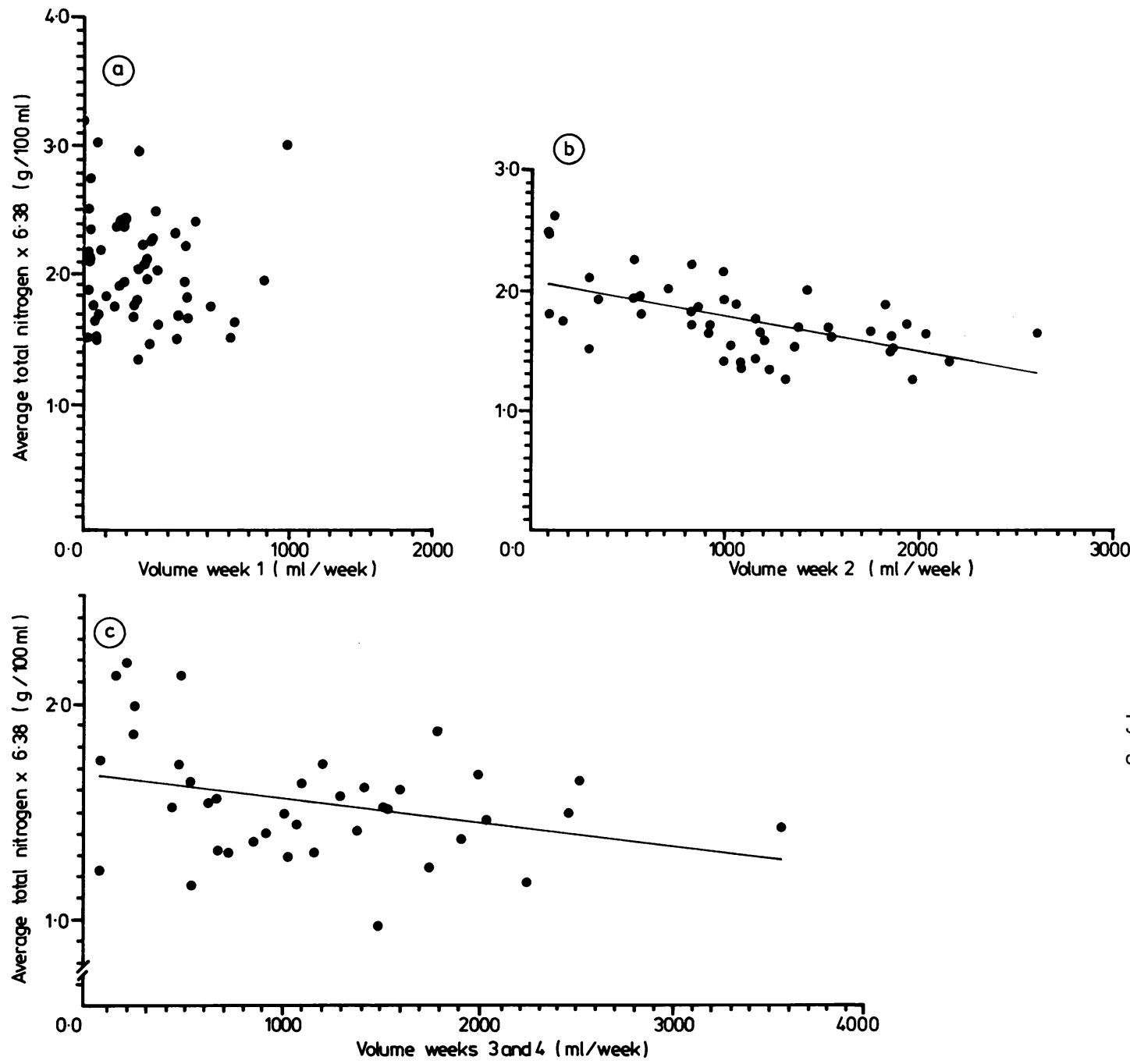

Fig. 3 The average protein content for each mother in the study is plotted against her recorded average volume output for: (a) week 1 ; (b) week 2; (c) weeks 3 and 4.

Beyond week two, Fig. 3 (c) shows that five of 22 donors $(23 \%)$ produced milk with an average protein content of as low as $1.3 \mathrm{~g} / 100 \mathrm{ml}$ or less.

Because of the statistical possibility that those mothers who were no longer in the study during the later weeks constituted a 'special group' that might bias the results, we analysed the data excluding this group at all postnatal ages. We found that exclusion of this group did not influence the relation between protein content and either postnatal age or milk volume produced.

\section{Discussion}

The protein requirements of low birthweight infants $N$ are still disputed but several groups have recommended that intakes should be higher than in infants born at term, to promote intrauterine growth per- $\mathrm{\omega}$ formance and prevent hypoproteinaemia. ${ }^{7-9}$ Based on an extensive review of published work, the $\bullet$ preliminary recommendation of the $\operatorname{ESPGAN}^{6} \mathbb{\varnothing}$ committee on feeding the low birthweight infant is that protein intakes of formula fed preterm infants 
should be in the range 2.9 to $4.0 \mathrm{~g}$ protein $/ \mathrm{kg}$ per day. It has not been established that the minimum requirement for protein is lower in preterm infants fed on human milk than those fed on modern casein:whey adjusted formulae. A principal purpose of our investigation was to explore certain aspects of the biology of preterm milk in an unselected population of donors to determine whether the higher protein concentrations reported (in preterm compared with term milk) meet the theoretical standards, cited above, for preterm infant feeding.

The decline in protein concentration in term human milk during the early weeks of lactation has been well documented by many groups. ${ }^{10-12}$ Since milk volume output rises over a corresponding period, the decreasing protein concentration might represent more a 'dilution' effect rather than a decrease in the protein synthesis rate of the mammary gland; indeed, Hytten ${ }^{13}$ reported a negative correlation between milk protein concentration and 24 hour milk volume output in term milk. This argument is pertinent to the interpretation of the high protein concentration in preterm milk. Preterm milk must be obtained by manual or mechanical expression of the breast and the volumes collected may be substantially less than those produced during normal suckling of the term infant (see Figs. 2 and 3 ): indeed, we have observed previously that only $15 \%$ of a large population of infants received more than $80 \%$ of their enteral intake as maternal milk. ${ }^{5}$

This study has shown that there is a strong negative correlation between preterm milk protein concentration and the volume of milk collected and this observation accords with that reported previously in a small population of preterm milk donors up to day $14 .{ }^{14}$ Others, however, ${ }^{15}$ have failed to find a volume effect of significance and this may have related to the much higher volumes of preterm milk obtained in their study; indeed, we observed that the decline in milk protein concentration with increasing milk volume was smaller at higher volume outputs (and therefore the relation may not be described best as linear). Our findings indicate that high mean preterm milk protein concentrations (similar to the range incorporated into special modern preterm formulae; that is 1.8 to $2.0 \mathrm{~g} / 100$ $\mathrm{ml}$ ) are found usually in relatively low volume output donors who would not be able to supply their infants' fluid volume needs (Fig. 3 (a)). In contrast, mothers who produce sufficient volumes to feed fully their own infants, secrete milk that fails frequently to meet the theoretical protein intake requirements of preterm neonates. Indeed, as a corollary, our findings suggest that if a mother produces greater volumes of milk than are required to feed an extremely low birthweight infant, the chances that theoretical protein intake requirements will be met are smaller than if she produces an amount appropriate to her infant's volume needs.

This study shows that three factors may influence the probability that a mother will meet fully the calculated protein needs of her infant. Firstly, as discussed above, the volume of milk produced is an important determinant of protein content. Secondly, as shown also by other workers, the postnatal age of the donor is correlated negatively with milk protein concentration (Fig. 1). Thirdly, although neither milk volume output nor protein content were found to correlate with birthweight, the lower the infant's weight, the greater the chance that total protein requirements will be supplied by a donor who is producing a relatively small milk volume (compared with that required for a term infant) and containing, therefore, a relatively high protein content.

In the present study the conventional assumption has been made that milk protein concentration equals total nitrogen $\times 6 \cdot 38$. There is little information on the extent to which this equation might indeed overestimate available protein in preterm milk. Our own studies and those of others ${ }^{2} 16-19$ indicate that a significant portion of total nitrogen in early preterm milk represents either non-protein nitrogen or immunoglobulin, though it remains to be established whether or not some of these components may be utilised. Our (unpublished) data suggest that the relation between total nitrogen and milk volume is similar to that between precipitable protein nitrogen and volume output.

Our findings serve to indicate that it is not possible to make a general statement on the suitability of preterm milk, in terms of its protein content, for feeding low birthweight infants. Although mothers fail frequently to meet their infants' theoretical protein requirements, it is apparent that some secrete preterm milk with a high protein concent: thus, adding protein supplements to preterm milk (currently under investigation by several groups), ${ }^{7}$ if practised as an indiscriminate policy, could result, in some instances, in protein intakes greater than those recommended, and the potential dangers of protein overload (metabolic acidosis, hyperaminoacidaemia, poor growth, and neurological damage) must be considered.

Clearly, any assessment of the advantages and disadvantages of preterm milk in the nutrition of low birthweight neonates must depend on factors other than protein content alone. If, however, it is considered desirable to use preterm milk, it could be argued that theoretical protein requirements are more likely to be met if this is used in conjunction 
with a specially designed formula, rather than as a sole diet.

Whether or not preterm milk has a higher protein content than term milk and therefore represents a unique biological secretion is disputed. ${ }^{14} 15$ Our observations suggest that at least a major explanation for its high protein content is the low volume produced by many donors, and in one report ${ }^{14}$ preterm and term milks were found to have the same protein content when volume was taken into account. Further studies on the biology of preterm milk may prove valuable in defining the circumstances in which preterm milk donors are likely to supply low birthweight infants with their theoretical needs for protein (and other nutrients). On the basis of our reported findings we are investigating the predictive value of model calculations based on the donor's postnatal age, milk volume output, infant's weight, and on their individual milk protein concentration during the early days of lactation. Our present findings indicate that although the considerable variability of preterm milk composition is a potentially major problem in clinical practice, at least an important component of this variability is predictable when account is taken of the biology of preterm milk secretion.

We thank P M V John of this laboratory for skilled technical assistance and Sister Penny Lucas and the staff of the Special Care Baby Unit, Mill Road Maternity Hospital, Cambridge for their help and cooperation.

\section{References}

1 Atkinson SA, Bryan MH, Anderson GH. Human milk: difference in nitrogen concentration in milk from mothers of term and premature infants. $J$ Pediatr 1978;93:67-9.

2 Schanler RJ, Oh W. Composition of breast milk obtained from mothers of premature infants as compared to breast milk obtained from donors. J Pediatr 1980;96:679-81.

${ }^{3}$ Gross SJ, David RJ, Bauman L. Tomarelli RM. Nutritional composition of milk produced by mothers delivering preterm. J Pediatr 1980;96:641-4.
+ Gross SJ. Growth and biochemical response of preterm infants fed human milk or modificd infant forumla. $N$ Engl J Med 1983:308:237-41.

5 Lucas A. Availability of preterm milk. Lancet 1983;i:1(145-6.

- ESPGAN Committee on Nutrition. Interim report. Proceedings of the European Society of Pediatric Gastroenterology and Nutrition 1983.

${ }^{7}$ Ronnholm KAR, Sipila I, Siimes MA. Human milk protein supplementation for the prevention of hypoproteinaemia without metabolic imbalance in breast milk fed very low birthweigh infants. J Pediatr 1982:101:243-7.

* Davidson M, Levine S, Bauer C, Dann M. Feeding studies in low birthweight infants. J Pediatr 1967:70:695-713.

"Senterre J. In: Visser HK. ed. Nutrition and metabolism of the fetus and neonate. The Hague: Nijhoff, 1979:195.

II) Macy IG, Kelly HJ. In: Kon SK, Cowic AT, eds. Milk, the mammary gland and its secretion. Vol II. London: Academic Press, 1961:265-304.

1 Lonnerdal B, Forsum E, Hambracus L. A longitudinal study of the protein. nitrogen and lactose contents of human milk from Swedish malnourished mothers. Am J Clin Nutr 1976;29: 1127-33.

12 Jensen RL. Thomas LN, Bergmann KE, Filer LJ Jr, Fomon SJ. In: Fomon SJ, ed. Infant nutrition. 2nd ed. Philadelphia: WB Saunders, 1974:359-4()7.

13 Hytten FE. Clinical and chemical studies in human lactation. IV. Trends in milk composition during course of lactation. $\mathrm{Br}$ Med J 1954;i:249-53.

14 Anderson DM, Williams FH, Merkatz RB, Schulman PK, Kerr DS, Pittard WB III. Length of gestation and nutritional composition of human milk. Am J Clin Nutr 1983;37:810-4.

15 Anderson GH. Human milk composition: effect of premature birth and milk volume. Am J Clin Nutr 1984;39:168-9.

16 Atkinson SA. Anderson GH, Bryan MH. Human milk: comz parison of the nitrogen composition in milk from mothers of premature and full-term infants. Am J Clin Nutr 1980;33:811-5

17 Gross SJ, Buckley RH, Wakil SS, McAllister DC. David RJ Faix RG. Elevated IgA concentration in milk produced by mothers delivered of preterm infants. J Pediatr 1981;99:389-93.

16 Suzuki S, Lucas A, Lucas PJ, Coombs RRA. Immunoglobulin concentrations and bacterial antibody titres in breast milk from mothers of 'preterm' and 'term' infants. Acta Paediatr Scand 1983;72:378-82.

19 Hibberd C, Brooke OG, Carter ND, Wood C. A comparison of protein concentrations and energy in breast milk from preterm and term mothers. J Hum Nutr 1981;35:189-98.

Correspondence to Dr A Lucas, Dunn Nutrition Unit, Downhams Lane, Milton Road, Cambridge CB4 1XJ.

Received 26 April 1984 